\title{
Climate change mitigation options among farmers in South Asia
}

\author{
Jeetendra Prakash Aryal ${ }^{1}$ (D) - Dil Bahadur Rahut ${ }^{1}$ (D) Tek B. Sapkota $^{2}$ (D) . \\ Ritika Khurana $^{3}$ - Arun Khatri-Chhetri ${ }^{4}$ (D)
}

Received: 28 October 2017 / Accepted: 2 March 2019 / Published online: 21 March 2019

(c) The Author(s) 2019

\begin{abstract}
Agriculture in South Asia is highly vulnerable to climate change due to increasing variability in rainfall and rising temperatures leading to the incidence of extreme climatic events such as floods, droughts, heat/cold waves, and storms. Agriculture sector also contributes to the causes of climate change through the emission of greenhouse gasses (GHGs). Hence, adaptation-led mitigation measures are required to sustain agricultural productivity, farm income and reduce GHG emissions wherever possible. This study presents a systematic review of agriculture emission reduction opportunities with a particular focus on agricultural production systems in South Asia. Our review indicates that the adoption of better soil, water, nutrient management practices, and technologies has enormous potential to reduce GHG emissions from agriculture, thereby contributing to the mitigation of climate change. Many existing practices and technologies have the potential to improve both adaptation and mitigation in agriculture which can significantly contribute to complying with nationally determined contributions (NDCs) of South Asian countries. However, barriers to the adoption of GHG mitigating agricultural practices, mainly the financial and institutional barriers, need to be appropriately addressed to achieve the desired level of mitigation.
\end{abstract}

Keywords Climate change $\cdot$ Greenhouse gas mitigation $\cdot$ Agriculture $\cdot$ South Asia

JEL Classification Q18 · Q54

Dil Bahadur Rahut

dilbhutan@gmail.com; d.rahut@cgiar.org

1 International Maize and Wheat Improvement Center (CIMMYT), Carretera México-Veracruz Km. 45 El Batán, C.P. 56237 Texcoco, Mexico

2 International Maize and Wheat Improvement Center (CIMMYT), New Delhi, India

3 West Virginia University, Morgantown, USA

4 CGIAR Research Program on Climate Change, Agriculture and Food Security (CCAFS), BISA, International Maize and Wheat Improvement Center (CIMMYT), New Delhi, India 


\section{Introduction}

The nationally determined contributions (NDCs) of all South Asian countries proposed their contribution to climate change mitigation efforts and local adaptation actions with individual country's national priorities. According to the recent report of the Intergovernmental Panel on Climate Change (IPCC), the current level of emissions of greenhouse gases (GHG) needs to be reduced considerably to limit the temperature rise to below $2{ }^{\circ} \mathrm{C}$ (UNFCCC 2015). Although contribution from the agriculture sector to global emissions is lower than industrial, energy, and other sectors, it has substantial potential to contribute to global emission mitigation supplemented by appropriate adaptation options.

Issues on agriculture for climate action were in the agenda under the UNFCCC's Subsidiary Body for Scientific and Technological Advice (SBSTA) in COP17 in Durban, but it did not define the way forward. The COP21 in Paris placed the agriculture sector under priority for climate action but the major stride on this was not observed until COP 23 (UNFCCC 2017). The COP23 in Bonn took a major step to prioritize agriculture in climate action and established the Koronivia joint work on agriculture to design and realize new strategies for adaptation and mitigation in the agriculture sector to reduce emissions.

A wide range of mitigation options in agriculture have been proposed based on the evaluation of practices and technologies in different agricultural production systems in South Asia. Changes in soil, water, and nutrient management practices and adoption of climatesmart technologies can significantly reduce GHG emissions from croplands (Ahmad et al. 2013; Aryal et al. 2015a, b; Sapkota et al. 2015a, b; Singh et al. 2010). Similarly, feed inputs and manure management have enormous potential to reduce emissions from the livestock sector (Gerber et al. 2013a, b; Vetter et al. 2017). Despite substantial potential for GHG mitigation from the agriculture sector, national and subnational governments in the region do not prioritize agricultural mitigation options in their NDCs. Nevertheless, their priorities on adaptation initiatives such as water and crop, crop management, value chain interventions, and landscape-level actions have substantial potential for generating mitigation co-benefits.

Given the increasing emphasis on climate-change mitigation, an important research gap is that mitigation options in agriculture have not been assessed and presented to the key stakeholders of adaptation and mitigation in agriculture. We systematically reviewed all available literature on agriculture mitigation options and their potential contributions to reducing GHG emissions. This study provides rich information about the potential of GHG emission reduction through the application of different practices and technologies in crop and livestock production systems in South Asia.

\section{Agricultural emissions}

Agriculture, forestry, and other land use (AFOLU) account for $24 \%$ of anthropogenic GHG emissions globally (about 9-12 $\mathrm{GtCO}_{2} \mathrm{e}$ year ${ }^{-1}$ ), mainly from deforestation and agricultural emissions (Smith et al. 2014). The livestock sector alone contributes to $14.5 \%$ of the total human-induced GHG emissions (IPCC 2014; Gerber et al. 2013a, b). GHG emissions from the AFOLU sector differ among the South Asian countries. For instance, the AFOLU sector as a whole accounts for more than $80 \%$ of the total GHG emissions in Nepal (Pradhan et al. 2017). Methane from enteric fermentation and rice cultivation and nitrous oxide, 
mainly from soil and fertilizer application, are major contributors to agricultural GHG emissions. For the period 1970-2010, the emission of methane increased by 20\%, whereas emissions of nitrous oxide increased by 45-75\%, mostly in Asia (Smith et al. 2014). Within Asia, South Asia has the largest share of methane emissions. The livestock sector and paddy production are the primary sources of methane emissions, whereas the application of manures and fertilizers is the largest source of nitrous oxide emissions. From rice cultivation only, South Asia emits almost $4900 \mathrm{Gg}$ methane per year, which is the third-highest level of methane from rice cultivation globally (IRRI 2018).

We noted that in South Asia, the emission of nitrous oxide from agriculture has increased over time due to the increased application of fertilizer. For instance, between 2003 and 2010, the fertilizer application in India increased from 105 to $179 \mathrm{~kg} \mathrm{ha}^{-1}$, in Pakistan from 106 to $217 \mathrm{~kg} \mathrm{ha}^{-1}$, in Bangladesh from 160 to $184 \mathrm{~kg} \mathrm{ha}^{-1}$, in Sri Lanka from 231 to $259 \mathrm{~kg} \mathrm{ha}^{-1}$, and in Nepal from 5 to $23 \mathrm{~kg} \mathrm{ha}^{-1}$ (World Bank 2013a). GHG emission from agriculture is more likely to increase in South Asia due to the need for producing more food to satisfy the food demand of the increasing population. In addition, higher mechanization and the use of groundwater irrigation could increase energy consumption from the agriculture sector and hence substantially increase GHG emissions. Against the backdrop of global warming, rapid climate change, the substantial contribution of agriculture to global warming, and the vulnerability of agriculture to climate change, the objective of the current paper is to review these inter-linkages. As South Asia consists mainly of agrarian countries which are highly vulnerable to climate change, the current paper focuses exclusively on South Asia.

Figure 1 (upper section) exhibits an increase in methane emissions in South Asian countries in 2010 compared to 1990. The share of agricultural emissions in total methane emissions ranges between 70 and $80 \%$ in all countries under study. If methane emissions from agriculture between 1990 and 2010 are compared, the largest increase is found in Pakistan $(47.1 \%)$, whereas a decline in methane emission was observed in Sri Lanka. Figure 1 (lower section) indicates a sharp increase in nitrous oxide emissions over the last two decades. Between 1990 and 2010, the percentage increase in total emissions of nitrous oxide was largest in Bangladesh (72.7\%), followed by Pakistan (62.9\%) and India (46.8\%). From 1990 to 2010, the percentage increase in nitrous oxide emissions from agriculture was found to be highest in Bangladesh (about 80\%) and lowest in Sri Lanka (9\%). As shown in Fig. 1, the share of individual countries in South Asia in total emission of nitrous oxide in 2010, India remained on top with a share of $77 \%$.

Unlike $\mathrm{CH}_{4}$ and $\mathrm{N}_{2} \mathrm{O}, \mathrm{CO}_{2}$ is cycled in large amounts through agricultural production systems. Plants consume a large amount of $\mathrm{CO}_{2}$ through the process of photosynthesis, but most of the plant products, including grains, fruit, residue, and root biomass, are eventually converted back to $\mathrm{CO}_{2}$ when consumed or when they decompose. Considering the total pool cycling in the system, the net emission of $\mathrm{CO}_{2}$ is small in agriculture and, therefore, not presented in detail. However, energy use on farms and emissions due to the production and transport of agricultural inputs constitute a substantial portion of $\mathrm{CO}_{2}$ emissions.

Figure 2 shows the GHG (methane) emissions from livestock for meat and milk. GHG emissions from livestock meat in six South Asian countries (Bangladesh, Bhutan, India, Nepal, Pakistan, and Sri Lanka) increased by 24\%, from 338,413 gigagrams (Gg) in 1990 to $419,549 \mathrm{Gg}$ in 2014 , and GHG emissions from livestock milk increased by $69 \%$, from $125,312 \mathrm{Gg}$ to $211,291 \mathrm{Gg}$ (FAOSTAT 2017).

The GHG emissions from livestock meat is highest for India, which is about $300,995 \mathrm{Gg}$, followed by Pakistan $(81,899 \mathrm{Gg})$, Bangladesh $(21,381 \mathrm{Gg})$, Nepal $(14,034 \mathrm{Gg})$, Sri Lanka (1103 Gg), and Bhutan (137 Gg). The GHG emission from 


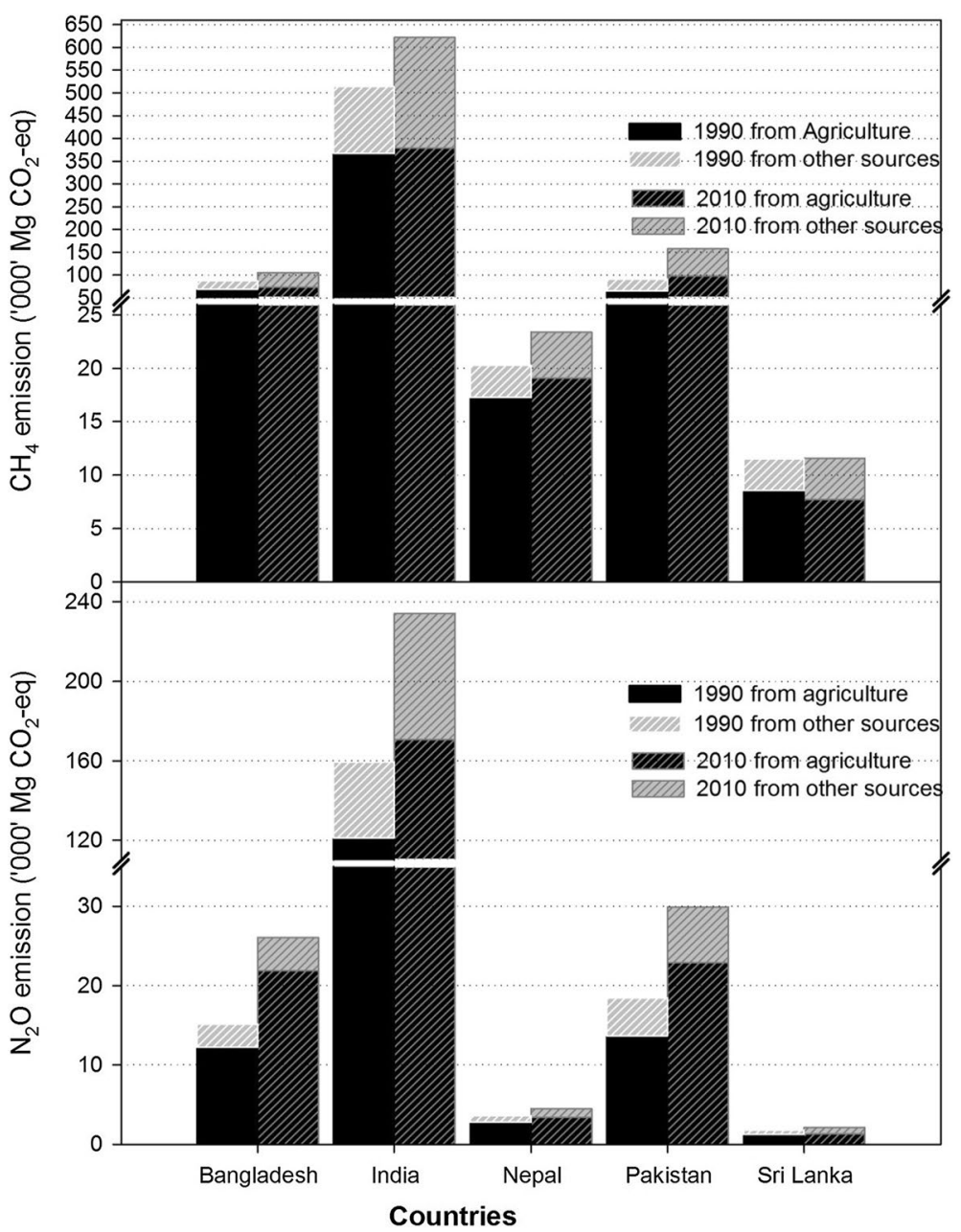

Fig. 1 Share of methane and nitrous oxide emissions from agriculture. Data source: World Bank (2013a)

livestock milk is the highest for India, which is about $141,534 \mathrm{Gg}$, followed by Pakistan (50,562 Gg), Bangladesh (14,196 Gg), Nepal (4126 Gg), Sri Lanka (656 Gg), and Bhutan $(217 \mathrm{Gg})$. The GHG emissions from Bhutan and Sri Lanka are small compared to other South Asian countries; the share of GHG emissions from livestock from Bhutan is less than 1\%, while it is about $70 \%$ for India and $20 \%$ for Pakistan.

The GHG emissions from livestock (meat and milk) increased substantially in 2014 compared to 1990 for all South Asian countries except Bhutan and Sri Lanka. During the same period, the GHG emissions from livestock (meat) decreased by $34 \%$ in Bhutan and 54\% in Sri Lanka, while the GHG emissions from livestock (milk) decreased by $8 \%$ in Bhutan and $18 \%$ in Sri Lanka. 


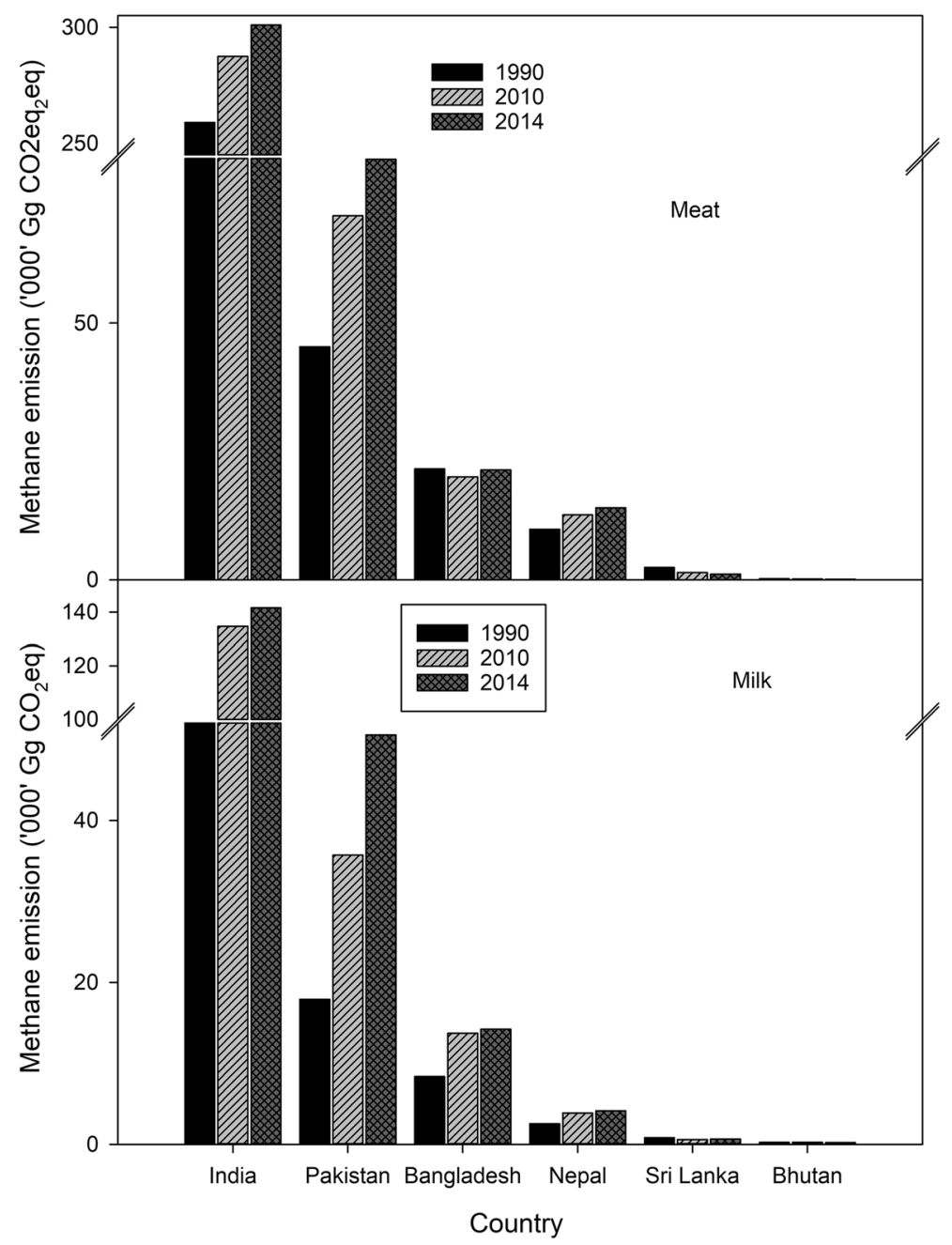

Fig. 2 Share of methane emission from livestock products. Data source: FAOSTAT (2017)

\section{Greenhouse gas mitigation options in the agricultural sector and their abatement potential}

Improving the efficiency of production through the adoption of better agricultural practices not only reduces emissions of GHGs from agro-ecosystems but also sequesters atmospheric carbon into terrestrial ecosystems (Sapkota et al. 2017a, b). Globally, agriculture accounts for about $14 \%$ of the annual increase in anthropogenic GHG emissions, mainly through methane and nitrous oxide (Smith et al. 2008). Therefore, mitigation efforts in agriculture could significantly reduce GHG emissions (Nelson 2009). Mitigating GHG is possible either by the sequestration of $\mathrm{CO}_{2}$ or the reduction in $\mathrm{CH}_{4}$ and $\mathrm{N}_{2} \mathrm{O}$ emissions. Livestock has the potential to contribute to climate change mitigation either by reducing greenhouse gas emissions or through increasing soil carbon sequestration (Mottet 
et al. 2017). Agriculture, forestry, and other land use (AFOLU) contribute to about 24\% (approximately $10-12 \mathrm{GtCO}_{2} \mathrm{e}$ year ${ }^{-1}$ ) of anthropogenic GHG emissions, primarily from deforestation and agricultural emissions from livestock, soil, and nutrient management (IPCC 2014). The annual GHG emissions from agricultural production from 2000 to 2010 were estimated at 5.0-5.8 $\mathrm{GtCO}_{2}$ e year ${ }^{-1}$ (IPCC 2014). The IPCC (2014) estimates that the economic mitigation potential of supply side measures in the AFOLU sector will be 0.49-10.60 $\mathrm{GtCO}_{2} \mathrm{e}$ year ${ }^{-1}$ by 2030 for mitigation efforts consistent with carbon prices up to USD100 per $\mathrm{tCO}_{2} \mathrm{e}$. Estimates from the agricultural sector only range from 0.3 to $4.6 \mathrm{GtCO}_{2} \mathrm{e}$ year ${ }^{-1}$ at prices up to USD100 per $\mathrm{tCO}_{2} \mathrm{e}$, and estimates from the forestry sector only range from 0.2 to $13.8 \mathrm{GtCO}_{2} \mathrm{e}$ year ${ }^{-1}$ at prices up to $\mathrm{USD} 100$ per $\mathrm{tCO}_{2} \mathrm{e}$.

Table 1 presents that sustainable land management (SLM) practices help mitigate GHG emission from agriculture irrespective of the climate zone. In cool-moist, warm-moist, and warm climatic zones, improved agronomic practices more efficiently reduce GHG emissions from agriculture. Cover crops and fallow rotation suits warm and moist climates the best, annually mitigating $0.98 \mathrm{tCO}_{2} \mathrm{e} \mathrm{ha}^{-1}$ (tons of carbon dioxide per hectare), while nutrient management performs the best in cool-to-warm and moist climates. In cool-dry climatic zones, agroforestry is the most effective method, as it reduces GHG emissions by $1.17 \mathrm{tCO}_{2} \mathrm{e} \mathrm{ha}{ }^{-1}$ year $^{-1}$. Irrespective of the climatic zone, better water management, including irrigation, contour farming, bunds, and water harvesting, can mitigate GHGs $1.14 \mathrm{tCO}_{2} \mathrm{e} \mathrm{ha}^{-1}$ year $^{-1}$.

The following sections present a summary of the mitigation options in the agricultural sector together with their mitigation potentials with a particular focus on South Asia.

\subsection{Conservation agriculture}

Conservation agriculture (CA) refers to agricultural practices that are based on three principles: minimal soil disturbance, permanent soil cover, and crop rotation (Kassam et al. 2009). CA is an important management strategy to address multiple challenges of sustainable food production, climate change adaptation, and mitigation (Gupta and Seth 2007). For example, zero tillage (ZT) is reported to increase soil organic carbon SOC and improve several other soil-quality parameters compared to conventional tillage (CT) systems (Gathala et al. 2011). Plow-based agriculture exacerbates the problems of accelerated soil erosion by water and wind, oxidation of soil organic matter and disrupts soil aggregation (Lal 2015), all leading to the loss of SOC from agro-ecosystems. ZT, on the other hand, helps in accumulating SOC by reducing net mineralization of soil organic matter and by promoting soil aggregation (Sapkota 2012). In a long-term experiment, (Gil et al. 2009) found a $10 \%$ higher organic-matter concentration and a 55\% higher total $\mathrm{N}$ in ZT than in the moldboard plow-based system mainly in surface $0.05 \mathrm{~m}$ depth. However, the literature on the influence of ZT on SOC concentration still remains inconsistent, as many other researchers (Baker et al. 2007; Halvorson et al. 2002; Thomas et al. 2007; West and Post 2002) reported no significant increase in SOC between ZT and CT. Variation in crops, climate, and soils is probably the primary reasons for such inconsistencies in the findings. By analyzing the tropical dataset, Powlson et al. $(2014,2016)$ argued that the rate of SOC increase in ZT systems in the Indo-Gangetic Plains (IGP) could be around $0.3 \mathrm{Mg} \mathrm{C}^{-1}$ year $^{-1}$ in a $0-0.3 \mathrm{~m}$ soil layer. Similarly, Grace et al. (2003) estimated that $\mathrm{CO}_{2}$ equivalent emissions from conventionally tilled cropping systems (rice-wheat system) would be about $29 \mathrm{MgCO}_{2}$ year $^{-1}$ if applied to one million hectares of the Indo-Gangetic Plains, while this is lowered to $14 \mathrm{MgCO}_{2}$ year $^{-1}$ if a ZT system with residue retention is applied to the same. 


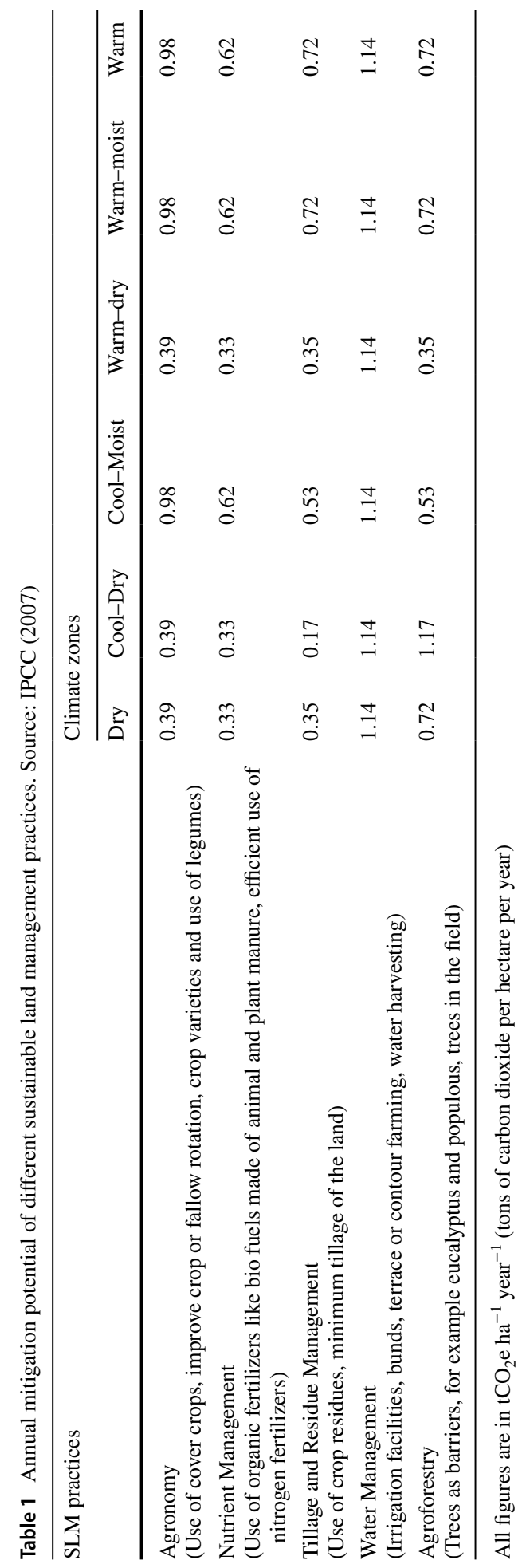


Another study (Grace et al. 2012) shows that the rice-wheat system of India has the potential to sequester $44,100 \mathrm{Gg} \mathrm{C}$ over 20 years if it is converted to ZT. This study estimated that adopting ZT in maize-wheat and cotton-wheat systems in India can sequester $6600 \mathrm{Gg}$ C during the same period. A study by (Aryal et al. 2015b) shows that shifting from CT to ZT based on wheat production reduces $\mathrm{GHG}$ emissions by $1.5 \mathrm{MgCO}_{2}$-eq $\mathrm{ha}^{-1}$ year $^{-1}$. Recently, Sapkota et al. $(2017 \mathrm{a}, \mathrm{b})$ reported soil carbon increases by $4.7 \mathrm{Mg} \mathrm{C}^{-1}$ after seven years of CA (ZT with partial residue retention) in the rice-wheat systems of the Eastern Indo-Gangetic Plains of India.

Conventional puddle transplanted rice (TPR) is a major source of methane emissions. Adoption of direct-seeded rice (DSR), which does not require puddling of the field during transplanting, is thus a feasible alternative to mitigate GHG emissions from agriculture (Sapkota et al. 2015a, b). This saves water and labor requirements for planting. A study in Punjab state of India (Pathak et al. 2013) showed that the total global warming potential of TPR ranged from 2.0 to $4.6 \mathrm{tCO}_{2} \mathrm{e} \mathrm{ha}^{-1}$, while it ranged from 1.3 to $2.9 \mathrm{tCO}_{2} \mathrm{e} \mathrm{ha}^{-1}$ in the DSR. Their study claimed that if the entire area under TPR in Punjab state is converted to DSR, the global warming potential from paddy cultivation can be reduced by $33 \%$ of the current emissions. Another way to reduce methane emissions is to incorporate organic manure in the alternate seasons (Xu et al. 2000; Cai and Xu 2004).

Crop residue management is one of the major components of $\mathrm{CA}$, and thus, it reduces the burning of crop residue. This means it also reduces the emission of $\mathrm{N}_{2} \mathrm{O}$ and $\mathrm{CH}_{4}$ as each ton of crop residue emits $40 \mathrm{~g}$ of $\mathrm{N}_{2} \mathrm{O}$ (equivalent to $12.4 \mathrm{~kg}$ of $\mathrm{CO}_{2}$ ) and $2.3 \mathrm{~kg}$ of $\mathrm{CH}_{4}$ (equivalent to $48.3 \mathrm{~kg}$ of $\left.\mathrm{CO}_{2}\right)($ Grace et al. 2003).

\subsection{Laser land leveling}

Laser land leveling helps reduce GHG emissions from several farm operations, especially by reducing the demand for irrigation water and the resultant reduction in energy requirements for pumping it. In addition, it reduces $10-15 \%$ in the operating time of agricultural machinery in the field, thereby saving a considerable amount of energy use for farming operations (Rickman 2002). Compared to the traditionally leveled field, in the laser-leveled fields of Punjab and Haryana, irrigation time in the rice-wheat (RW) system is reduced by almost $70 \mathrm{~h} \mathrm{ha}^{-1}$ rotation $^{-1}$ (Aryal et al. 2015a). As a result, the RW system in a hectare of laser-leveled field required almost $754 \mathrm{kWh}$ less electricity for irrigation per year compared to a traditionally leveled field (Aryal et al. 2015a). Gill (2014) estimates that under the existing system of electricity generation in India, the use of laser land leveling reduces about $0.15 \mathrm{Mg}$ of $\mathrm{CO}_{2}$ eq year ${ }^{-1} \mathrm{ha}^{-1}$ due to the decreased pumping time of water for irrigation and decreased cultivation time. In general, each liter of diesel consumed emits approximately $2.6 \mathrm{~kg}$ of $\mathrm{CO}_{2}$ (Grace et al. 2003). Besides, the LLL technology saves irrigation water and increases productivity (Ali et al. 2018).

\subsection{Site-specific nutrient management (SSNM)}

Fertilizers are a crucial input-driving food production, second to crop varieties. However, the intensified use of synthetic fertilizer has led to significant direct and diffuse environmental problems with over $60 \%$ of nitrogen pollution estimated to have originated from crop production alone (Sapkota et al. 2016). Recent reports by the IPCC and FAO revealed that synthetic fertilizers contribute $12-14 \%$ of the total global GHG emissions from agriculture (680-725 $\mathrm{TgCO}_{2}$-eq year ${ }^{-1}$ in 2010/2011). Fertilizer-use efficiency in South Asia 
is very low, i.e., 30-40\% (Farnworth et al. 2017; Tewatia et al. 2017). If we can increase fertilizer-use efficiency by $5-10 \%$, it will increase yield, reduce $\mathrm{N}_{2} \mathrm{O}$ emissions, and reduce the cost of production considerably, thereby providing higher profits to farmers (Majumdar et al. 2000). Precision agriculture, contrary to some views, is an approach that can be applied not only to large-scale mechanized farms but also to the management of inputs on smallholder farms in the tropics. Precision nutrient management aims to improve the efficiency of fertilizer use through ensuring that nutrients are applied in the right form, in the right amount, at the right time of plant uptake, and in the right place. These principles of good fertilizer management are applicable to fields over 1000 ha or less than 0.5 ha. All that changes are the tools. For example, leaf chlorophyll content can be linked with leaf $\mathrm{N}$ content and, therefore, measurement of leaf greenness by using a chlorophyll meter, leaf color chart, or optical sensors (e.g., GreenSeeker) can be used as the basis of in-season nitrogen management (Bijay-Singh et al. 2011, 2015). Similarly, computer/android phone-based decision support systems (e.g., Nutrient Expert, Crop Manager) are nowadays progressively being used to facilitate the application of improved nutrient-management practices in farmers' fields (Pampolino et al. 2012). Such tools have become increasingly important in geographies such as South Asia where blanket fertilizer recommendations prevail. Through on-farm comparison in over 4000 farmers' fields across the Indo-Gangetic plains of India, International Maize and Wheat Improvement Center (CIMMYT) found that 'nutrient expert'-based nutrient management reduced the GHG intensity of rice, wheat, and maize production by $5-35 \%$ (average $13 \%$ ) over farmers' fertilizer practices.

\subsection{Water management in rice}

Globally, flooded rice emits approximately 20,000-40,000 Gg of $\mathrm{CH}_{4}$ year ${ }^{-1}$, i.e., about $12 \%$ of anthropogenic emissions from the agriculture sector. India alone contributes around $5 \%$ of global $\mathrm{CH}_{4}$ emissions (Richards and Sander 2014; Wassmann et al. 2009). At the same time, rice production needs to be increased to meet the food demand of Asia's growing population. Given these challenges, developing technologies that enhance the yield yet render less harm to the environment is essential. Alternate wetting and drying (AWD) is a water management technique in rice that was developed in the 1970s to address the problem of increasing water scarcity in agriculture (Bouman and Tuong 2001). Under this system, rice fields are irrigated to the desired depth only and then re-irrigated after some time, when the water dissipates (Lampayan et al. 2015). IPCC (2006) Guidelines for National Greenhouse Gas Inventories claims a $48 \%$ reduction in methane emissions under AWD practices, whereas on-farm experiments on AWD shows 20-70\% reduction in methane emissions (Richards and Sander 2014). A study by LaHue et al. (2016) showed that AWD reduced growing-season methane emissions by $60-87 \%$ and maintained low annual nitrous oxide emissions. Uprety et al. (2012) also projected that AWD leads to a $60 \%$ decline in methane emissions.

Besides reduced $\mathrm{CH}_{4}$ emissions, AWD also makes rice production possible when water resources are scarce. Rice production with an AWD approach of water management saves 25-30\% of water compared to the conventional flooding (CF) system (Richards and Sander 2014; Siopongco et al. 2013). For instance, AWD required five fewer irrigations in 2010 and three fewer irrigations in 2011 compared to conventional flooding of rice fields. This accounted for a saving of $41.8 \%$ and $28 \%$ of water, respectively (Ye et al. 2013). AWD is believed to increase rice yield, although the results in yield are inconsistent (Bouman and 
Tuong 2001; Zhang et al. 2012). On the one hand, AWD is estimated to increase yield by $10 \%$ relative to CF (Yang et al. 2009; Zhang et al. 2009), while on the other hand, some studies refute this and claim no change or a slight decline in the yield (Yadav et al. 2012; Yao et al. 2012). Gathala et al. (2013) show that adopting AWD can save 30\% irrigation water in puddled transplanted rice, thereby reducing GHG emissions due to reduced energy used for pumping irrigation water. AWD reduces irrigation water input in rice fields by up to $38 \%$ without any reductions in rice yield (Lampayan et al. 2015). Therefore, AWD serves the twin purpose of mitigating GHG emissions by reducing methane and adapting to water stress.

\subsection{Improved livestock management}

Livestock contributes about $18 \%$ of global anthropogenic GHG emissions (Steinfeld et al. 2006). Total global emission from livestock between 1995 and 2005 was between 5.6 and 7.5 $\mathrm{PgCO}_{2} \mathrm{e}$ year ${ }^{-1}$ (Herrero et al. 2016). Of the total emissions from livestock systems, $\mathrm{CO}_{2}$ emitted from land use, its changes (including feed production and deforestation associated with it) accounts for $32 \%, \mathrm{~N}_{2} \mathrm{O}$ emitted from manure and slurry management occupies $31 \%$, and $\mathrm{CH}_{4}$ produced through enteric fermentation of ruminants accounts for $25 \%$ (Thornton and Herrero 2010). Adopting improved pastures, intensifying ruminants' diets, changing land-use practices, and changing breeds of ruminants can largely contribute to GHG mitigation from the livestock sector. Applying all these mitigation measures, the total mitigation potential becomes $417,000 \mathrm{Gg} \mathrm{CO}_{2} \mathrm{e}$, which is about $12 \%$ of the global livestock-related $\mathrm{CH}_{4}$ and $\mathrm{CO}_{2}$ emissions associated primarily with extensive livestock systems (Thornton and Herrero 2010; Steinfeld et al. 2006).

Table 2 presents options to reduce methane emission from the livestock sector. Mitigation options in the livestock sector include a range of diet and other management interventions that improve the efficiency of feed conversion, increase livestock productivity, and reduce emissions. In the context of smallholder production systems in South Asia, improved feed digestibility through the provision of highly digestible fodder (e.g., green fodder), and the inclusion of energy-dense food (i.e., increased concentrate feed), have considerable potential for mitigating GHG emissions from the livestock sector. For example, green fodder supplements and increased concentrate in the rations of ruminants in India would have the potential to mitigate ca. 3.4 $\mathrm{TgCO}_{2} \mathrm{e} \mathrm{year}^{-1}$ (Sapkota et al. 2019). Similarly, improved manure management through the establishment of large biogas plants has the potential to save ca. $9.3 \mathrm{TgCO}_{2}$ e year ${ }^{-1}$ in India.

Mitigation practices, however, cannot be generalized, and thus, each practice needs to be evaluated for an individual agricultural system based on the climatic, edaphic, social, and historical pattern of land use and management (Smith et al. 2007a, b). In addition,

Table 2 Potential of reducing methane emissions from the livestock sector through better management. Source: Smith et al. (2007a, b)

\begin{tabular}{llllll}
\hline Mitigation potential & Dairy cows & Beef cattle & Sheep & Dairy buffalo & Non-diary buffalo \\
\hline Improved feeding practice & 0.04 & 0.02 & 0.02 & 0.04 & 0.02 \\
Dietary additives & 0.01 & 0.01 & 0.0005 & 0.01 & 0.002 \\
Animal breeding & 0.01 & 0.01 & 0.001 & 0.01 & 0.02 \\
\hline
\end{tabular}

All the figures are in $\left(\mathrm{MgCO}_{2} \mathrm{e} \mathrm{head}^{-1}\right.$ year $\left.^{-1}\right)$ 
several non-climatic factors can influence climate change mitigation through its impact on farmer technology adoption.

\subsection{Agroforestry}

In the current climate-change scenario, agroforestry systems have attracted special attention in climate change mitigation and food security (Feliciano et al. 2018; Makundi and Sathaye 2004). Agroforestry systems yield multiple benefits, such as sustainable production, supporting household requirements through diversified productions, resource conservation, groundwater recharge, and environmental improvements. Agroforestry contributes to climate-change mitigation by storing carbon above ground in the form of biomass and below ground in the soil carbon. Soil organic carbon can be enhanced by planting trees and grasses in degraded lands (Kar et al. 2009). Agroforestry provides a solution to tillage, burning of leaf litter, deforestation, wildfires, and soil disturbance by storing carbon or minimizing emissions into the atmosphere. On average, carbon storage by agroforestry systems has been estimated to be around 9,21,50, and $63 \mathrm{Mg} \mathrm{C} \mathrm{ha}^{-1}$ in semiarid, subhumid, humid, and temperate regions, respectively (Jat et al. 2016). Globally, there is the potential to establish agroforestry systems on $585-1275 \times 10^{6}$ ha land, and this could store 12-228 (median 95) $\mathrm{Mg} \mathrm{C}^{-1}$ under current climate and edaphic conditions (Dixon 1995). Sathaye and Ravindranath (1998) projected that the mitigation potential of agroforestry systems in India is $25.4 \mathrm{Mg} \mathrm{C} \mathrm{ha}^{-1}$ and $29.7 \mathrm{Mg} \mathrm{C} \mathrm{ha}^{-1}$ in Pakistan.

\section{Synergies and trade-offs between adaptation and mitigation options in agriculture}

Most of the adaptation options in agriculture have GHG mitigating co-benefits, although this might differ across spatial and geographical characteristics. Valin et al. (2013) showed that closing yield gaps by $50 \%$ for crops and $25 \%$ for livestock by 2050 would decrease agriculture and land-use change emissions by $8 \%$. Improvement in crop yields would bring the largest food provision benefits, whereas livestock productivity gains would allow the greatest reductions in GHG emissions. Combining productivity increases in the two sectors appears to be the most efficient way to exploit mitigation and food security co-benefits (Valin et al. 2013).

In the agricultural sector, cropland adaptation options that also contribute to mitigation are: soil management practices that reduce fertilizer use and increase crop diversification; promotion of legumes in crop rotations, increasing biodiversity, the availability of quality seeds and integrated crop/livestock systems, promotion of low-energy production systems; avoiding burning of crop residues; and promoting efficient energy use by commercial agriculture and agro-industries (Smith et al. 2014). For example, site-specific nutrient management that is practiced as adaptation measures against declining yields due to climatic variability and enhances nutrient use efficiency also reduces $\mathrm{N}_{2} \mathrm{O}$ emissions from agriculture (Sapkota et al. 2014). Mitigation benefits of some adaptation measures in the agricultural sector, such as the adoption of heat and water-stress seed varieties are not clear. For example, Sahbhagidhan used in India and the Sookhadhan varieties in Nepal have the advantage of over $0.8-1.2$ tons per hectare under drought and contribute immensely to climate change adaptation. However, its mitigation benefits are not yet clear. Similarly, agroforestry 
is an example of mitigation-adaptation synergy in the agriculture sector, since trees planted sequester carbon and tree products provide livelihoods to communities, particularly during drought years (Verchot et al. 2007).

Synergies and trade-offs also depend on technology type and the stage of its adoption. For example, in the case of direct seeding rice, in the initial years of adoption, it is found to have only GHG mitigation benefits (reduced methane emission and reduced $\mathrm{CO}_{2}$ due to reduced energy use for pumping water and land preparation), even though the adaptation benefits are not observed during the initial 3-4 years of adoption (measured as gain benefits over conventional transplantation methods) (Jat et al. 2014).

Farmers usually adopt farming technologies such as laser land leveling, zero tillage, and direct-seeded rice as measures for climate change adaptation, i.e., as a response to increasing water stress and/or rainfall variability. Some of these measures lead to substantial reductions in GHG emissions, i.e., mitigation of climate change (Aryal et al. 2015a; Sapkota et al. 2017a, b). In semiarid and arid regions such as Haryana and Punjab states of India, where more than $80 \%$ of agriculture is based on irrigation and increasingly relies on groundwater for irrigation, the use of laser land leveling not only increases crop yields but also reduces the environmental footprint (Aryal et al. 2015a; Jat et al. 2015). Zero tillage, mainly a mitigation strategy, not only sequesters carbon in the soil but also prevents soil degradation, maintains the nutrient level of the soil, improves soil quality, and ultimately enhances crop productivity and yield (Lal 2004). A recent study in India shows that conservation agriculture-based wheat production systems cope better with rainfall variability compared to the conventional tillage-based system (Aryal et al. 2016a, b). Similarly, rice management (direct-seeded rice) can be used to overcome a water crisis, but with high labor costs (Farooq et al. 2011). This will enrich water quality and control weeding which forms a part of the adaptation to climate change. At the same time, this conserves energy resources and sequesters carbon, thereby lowering GHG emission levels. Alternate wetting and drying is another way to adapt to increasing water stress (Gathala et al. 2013).

There are trade-offs between adaptation and mitigation options in some cases. Farmers may use more water for irrigation to cope with rising temperatures. Recent studies show that water demand for irrigation in semiarid and arid regions could increase by $10 \%$ with a degree Celsius rise in temperature. To cope with such heat/temperature stress, farmers have to use more water for irrigation. Given that farmers in IGP are increasingly using groundwater for irrigation, they now require more energy for pumping irrigation water, which ultimately leads to more GHG emissions (Gill 2014). Farmers sometimes use fertilizers as a measure of adapting to declining soil fertility; however, this can lead to more $\mathrm{N}_{2} \mathrm{O}$ emissions (Celikkol Erbas and Guven Solakoglu 2017). This could also happen in the case of zero tillage (ZT) with residue retention, primarily due to immobilization (Sapkota et al. 2015a, b).

As per capita meat consumption in South Asia, mainly in India, is increasing, livestock production has become a profitable portfolio within agriculture. Still, livestock management is traditional, and feed management for GHG reduction is beyond the capacity of the majority of farmers in South Asia. The livestock sector emits higher levels of $\mathrm{CH}_{4}$, a gas with more potential to global warming. Improving feed practices and dietary patterns of livestock is a short-term measure which reduces the amount of $\mathrm{CH}_{4}$ released through enteric fermentation in ruminant animals. In the long run, structural and management changes along with animal breeding will have positive mitigation effects on $\mathrm{CH}_{4}$ and $\mathrm{N}_{2} \mathrm{O}$.

In Table 3, we provide a brief overview of the synergies and trade-offs between climate change adaptation and mitigation measures in the agricultural sector in South Asian countries, which is briefly described above. 


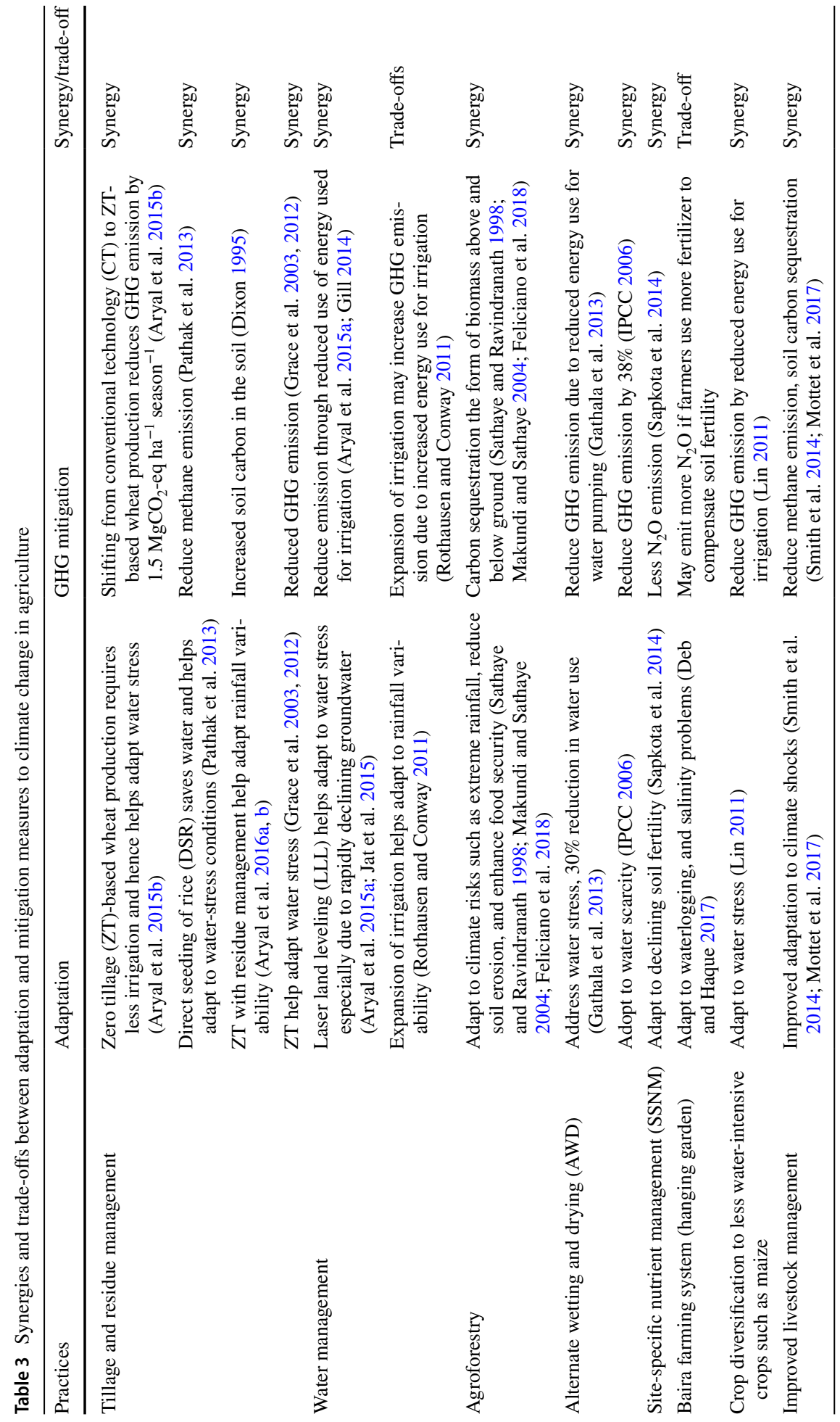




\section{Barriers to the adoption of mitigation measures in South Asia}

Croplands in South Asia are intensively managed and offer many opportunities to impose practices that reduce GHG emissions. All the crops, soil, and livestock management practices aimed toward increasing efficient use of water, nutrients, energy, and other production inputs, and those which increase crop/livestock production/productivity, lead to GHG mitigation. A bottom-up analysis in India, which can be generalized for South Asia, suggests that about $80 \%$ of the total technical mitigation potential $\left(67.5\right.$ out of $85.5 \mathrm{TgCO}_{2} \mathrm{e}$ year ${ }^{-1}$ ) in agriculture can be obtained by adopting cost-beneficial mitigation options (Sapkota et al. 2019). Cost-beneficial mitigation measures in South Asia that can be implemented through proper policy and programs include zero tillage, site-specific nutrient management, alternate wetting and drying in rice, provision of highly digestible fodder and inclusion of energy-dense food for livestock, and improved manure management. Many farmers are already adopting these measures. Still, adoption at scale is not taking place, indicating that there are barriers to overcome (Bustamante et al. 2014).

Despite the availability of a number of adaptation and mitigation measures to climate change in agriculture, many farmers still continue with conventional methods. Hence, a careful examination of factors that inhibit the adoption of such measures is direly needed. It should be noted, however, that farmers' adoption of any practice is difficult to project and largely depends on the sociopolitical environment under which the farmer operates. A better understanding of the sociopolitical environment and farmers' behaviors in relation to the adoption of these cost-beneficial GHG mitigation measures would help in designing appropriate policies, consistent with food security and sustainable development goals. Inaction is often justified on the ground of its uncertainty and also the conflicting scientific evidence. On the one hand, there is a need to increase farmer's knowledge on climate-smart agricultural practices (Aryal et al. 2018a), and on the other hand, the scientific community needs to ensure that the CSAPs are both cost-effective and user-friendly to the farmers (Aryal et al. 2019; Khatri-Chhetri et al. 2016). Other aspects of serious concern are a lack of immediate benefits of adopting such measures and the overall adaptive capacity of the concerned society.

Although farmers receive benefits from new technologies, shifting from the traditional to modern technologies has transaction costs in terms of knowledge accumulation, information gathering, and access to inputs required. Knowledge networks play a crucial role in enhancing farmers' understanding of CSAPs. Such networks help them to understand the trade-offs between the short-term costs and long-term benefits of CSAPs (Steenwerth et al. 2014). Most of the technologies may reap benefits after a critical scale of adoption. Agricultural technology adoption may benefit farmers equally, but whether the number of benefits is significantly higher to the individual farmer or not is a different issue. In the study of ZT wheat in Haryana, (Aryal et al. 2015b) found that though ZT wheat is more profitable to farmers in general, the total benefit is much smaller in the case of small and marginal farmers. This may be one of the reasons why small and marginal farmers do not adopt new technology or revert to the traditional methods once the project support is over.

\subsection{Financial barriers}

The financial capacity of South Asian farmers can hinder the adoption of GHG mitigating agricultural practices. Given the limited safety nets to cope with climate change, farmers 
may use less costly locally available adaptation measures that may not have mitigation cobenefits. The financial barrier is more likely to constrain GHG mitigation measures in agriculture sector of South Asia because farmers usually prioritize adaptation and the national mechanisms to finance GHG mitigating agricultural practices such as climate-smart agriculture is yet to develop (Patra and Babu 2017). Moreover, climate finance mechanism for GHG mitigation from agriculture sector lags behind other sectors (Buchner et al. 2017).

\subsection{Social and cultural barriers}

Aryal et al. (2014) found social and cultural issue such as gender is an important social barrier to having access to information. Women farmers in South Asia usually need assistances from their male relatives or neighbors to hire machineries required to apply climate-smart agriculture such as laser land leveling, Turbo Happy Seeder, etc. If there is no adult male member in the family, a general conceptual lock-in is observed in these societies, and still, women are not considered full-time farmers. Social and cultural barriers influence the adoption of new climate-smart agricultural practices that have both climate change adaptation and GHG mitigation benefits (Sapkota et al. 2015a, b). The social system defines the belief system of farmers, which is integral to decision making in the adoption of GHG mitigation measures in agriculture. The structure of the land tenure system and lack of clearly defined property rights may restrict farmers' adoption of CSAPs that have short-term costs but long-term benefits. Dual ownership patterns, for example, a land-to-the-tiller provision in some South Asian countries discouraged both landlord and tenant from investing in land management (Aryal and Holden 2013), which may serve both adaptation and mitigation benefits. In Bangladesh, almost $40 \%$ of the land is under the owner-tenant pattern, and this reduces the incentives to the tenant to apply land-conserving practices. In Andhra Pradesh, India, nearly 1.9 million (almost 42\%) of all rural low-caste and tribal households operate on insecure land rights (Landesa 2012). Such insecurities make the people more concerned with the short-term profits rather than the long-term sustainable use of land. Short-term tenants are less likely to invest in land conservation measures that have long-term mitigation benefits (Aryal and Holden 2013).

\subsection{Permanence}

Carbon sequestration is a proxy solution to reduce the effects of GHG emissions. To completely remove the carbon from the ecosystem, it may take decades and is contingent upon management practices (Smith et al. 2007a, b). For instance, shifting from conventional tillage (CT) to ZT may definitely result in sequestering $57 \pm 14 \mathrm{~g} \mathrm{C} \mathrm{m}^{-2}$, but on the wheat-fallow system, a change from CT to NT may not result in the desired amount of sequestration as a permanent solution (West and Post 2002). Therefore, what is needed is a permanent solution. Since carbon sequestration is time-bound, afforestation and biofuels are long-term permanent measures to counterbalance GHG emissions (McCarl and Sands 2007). 


\subsection{Institutional/policy barriers}

Lack of institutional support is one of the major reasons behind the low adoption of climate-change adaptation and mitigation measures by farmers. Studies have noted the lack of institutional support as the main reason for low adoption of climate-smart agriculture, which helps simultaneous achievement of GHG mitigation and climate change adaptation in agriculture (Aryal et al. 2018a, b, c, 2019; Sapkota et al. 2015a, b, 2019). Without the strong institutional setup and support, it is very unlikely that small farm households will adopt GHG mitigation measures. Investment on GHG mitigating measures in agriculture by South Asian farmers is low due to: (i) lack of awareness about climate change and its consequences; (ii) lack of knowledge about the adaptation and mitigation mechanisms and their benefits; (iii) lack of knowledge in implementing such methods and ability of poor farmers to invest in those tools and techniques; and iv) lack of financial support from government. In South Asia, the institutions at the local level are weak and do not have the capacity to assist in enhancing the adoption of climatechange adaptation and mitigation measures at the farm level. Thus, institutional support in the form of extension support, providing technological information, and subsidies can play major roles in scaling up GHG mitigation measures in agriculture sector in South Asia.

Lack of a clear policy, guidelines, and coordination between policies at different levels is also a major barrier for scaling up the adoption of climate-risk adaptation and mitigating strategies at the farm level. Climate change adaptation and mitigation policies for the agricultural sectors should start from the local level on up, and the national-level policy should be based on the local-level adaptation plan (Choudhary et al. 2002). In the South Asian context, such adaptation and mitigation policies could also be integrated at the regional level to have a greater impact on the region. The problem of low adoption of these measures arising from uncoordinated policies is further aggravated due to the presence of multiple stakeholders, as this sometimes leads to a dilution of responsibility.

Governance at different institutions related to formulation and implementation of policies at various levels is poor and lacks coordination, leading to duplication of efforts and, at times, gaps. Hence, the governance structure of the institutions working on climate-risk mitigation and adaptation scaling out should be coordinated. Vested interests and political agents have long opposed political or regulatory action in response to climate change by appealing to scientific uncertainty. Here, we examine the effect of such contrarian talking points on the scientific community itself (Lewandowsky et al. 2015).

Overall, the uncertainty of climate change has often been one of the major reasons for inaction. Contradictory and conflicting scientific evidence further add to this. While adopting mitigation measures, the public nature of its benefits and the problem of 'free riders' can also minimize its adoption. Existing institutional and policy structures especially the traditional extension services can further aggravate the problem. Therefore, institutional policies that address local issues and bridge the gaps between national, regional, and local climate change challenges are required (Aryal et al. 2016a, b). 


\section{Conclusions}

When focusing on climate change mitigation in agriculture, an assessment of potential options for adaptation and mitigation, their synergies and trade-offs, and key barriers for scaling out are essential. To this end, this detailed review of mitigation options in agriculture finds that there are many practices and technologies, which have low to high potential in reducing GHG emissions from agricultural production systems in South Asia. Our review of scientific studies indicates that simple changes in agronomic practices, such as tillage methods, water application, and nutrient management, can significantly reduce GHG emissions from agricultural lands. Furthermore, modification and promotion of traditional agroforestry systems and implementation of improved livestock management in the livestock-crop mixed-farming system also reduce large amounts of GHG emissions without reducing agricultural production. Many adaptation options have climate change mitigation co-benefits, which are mostly preferred by adaptation policy makers in South Asia. One of the primary objectives of a large number of smallholder farmers in the region is to improve farm productivity and income under climate change and variability. Therefore, promotion of adaptation options in agriculture that can improve farm productivity, income, and reduce climatic risks together with GHG mitigation benefits should be the main focus of national and subnational governments. This study also highlights that, despite mitigation requirements and farmers' interest in implementing adaptation and mitigation options, their lack of investment capacity, cultural and social behaviors, and lack of provision of incentives through policies and programs limit the adoption of GHG mitigation practices and technologies in agriculture.

This assessment of mitigation options provides critical evidence that can be incorporated into the national, subnational, and local-level adaptation and mitigation plans/programs such as the National Action Plan for Climate Change (NAPCC), National Adaptation Programme of Action (NAPA), and the Local Adaptation Plans of Action (LAPA) including the implementation of the nationally determined contributions (NDCs) of all South Asian countries. Scaling up and scaling out of the adaptation and mitigation options considered in this study can largely enhance the mitigation potential of the agriculture sector in South Asia as well as the ambition of achieving a goal of the Paris Agreement.

Acknowledgements The authors acknowledge the support of the CGIAR research programs (CRPs) on Climate Change, Agriculture and Food Security (CCAFS) and Wheat Agri-Food Systems (CRP WHEAT) for this study. CCAFS is supported from CGIAR fund donors and bilateral funding agreements (for details visit, https://ccafs.cgiar.org/donors). The CRP WHEAT receives W1\&W2 support from the Governments of Australia, Belgium, Canada, China, France, India, Japan, Korea, Netherlands, New Zealand, Norway, Sweden, Switzerland, U.K., U.S.A., and the World Bank. The views expressed here are those of the authors and do not necessarily reflect the views of the funders or associated institutions. The usual disclaimer applies, and the authors are responsible for any remaining errors and inferences.

Open Access This article is distributed under the terms of the Creative Commons Attribution 4.0 International License (http://creativecommons.org/licenses/by/4.0/), which permits unrestricted use, distribution, and reproduction in any medium, provided you give appropriate credit to the original author(s) and the source, provide a link to the Creative Commons license, and indicate if changes were made. 


\section{References}

Ahmad, A., Hoogenboom, G., Wajid, S. A., Khaliq, T., Ahmad, S., Naseem, W., et al. (2013). Climate Change Vulnerability of Rice Productivity in Pakistan. Paper presented at the ASA, CSSA, \& SSSA international annual meetings, Tampa, Florida, USA., Nov. 3-6, 2013.

Ali, A., Hussain, I., Rahut, D. B., \& Erenstein, O. (2018). Laser-land leveling adoption and its impact on water use, crop yields and household income: Empirical evidence from the rice-wheat system of Pakistan Punjab. Food Policy, 77, 19-32. https://doi.org/10.1016/j.foodpol.2018.03.018.

Aryal, J. P., Farnworth, C. R., Khurana, R., Ray, S., \& Sapkota, T. (2014). Gender dimensions of climate change adaptation through climate smart agricultural practices in India. Innovation in Indian agriculture: Ways forward. Institute of Economic Growth (IEG), New Delhi, and International Food Policy Research institute (IFPRI), Washington DC, New Delhi, India.

Aryal, J. P., \& Holden, S. T. (2013). Land Reforms, Caste Discrimination and Land Market Performance in Nepal. In S. T. Holden, K. Otsuka, \& K. Deininger (Eds.), Land Tenure Reform in Asia and Africa: Assessing Impacts on Poverty and Natural Resource Management (pp. 29-53). London: Palgrave Macmillan UK.

Aryal, J. P., Jat, M. L., Sapkota, T. B., Khatri-Chhetri, A., Kassie, M., Rahut, D. B., et al. (2018a). Adoption of multiple climate-smart agricultural practices in the Gangetic plains of Bihar, India. International Journal of Climate Change Strategies and Management, 10(3), 407-427. https://doi.org/10.1108/ IJCCSM-02-2017-0025.

Aryal, J. P., Jat, M. L., Singh, R., Gehlawat, S., \& Agarwal, T. (2016b). Framework, guidelines and governance for designing local adaptation plan of action to mainstream climate smart villages in India, International Maize and Wheat Improvement Center (CIMMYT), New Delhi, India.

Aryal, J. P., Mehrotra, M. B., Jat, M. L., \& Sidhu, H. S. (2015a). Impacts of laser land leveling in rice-wheat systems of the north-western indo-gangetic plains of India. Food Security, 7(3), 725-738. https://doi. org/10.1007/s12571-015-0460-y.

Aryal, J. P., Rahut, D. B., Jat, M., Maharjan, S., \& Erenstein, O. (2018b). Factors determining the adoption of laser land leveling in the irrigated rice-wheat system in Haryana, India. Journal of Crop Improvement, 32(4), 477-492. https://doi.org/10.1080/15427528.2018.1457584.

Aryal, J. P., Rahut, D. B., Maharjan, S., \& Erenstein, O. (2018c). Factors affecting the adoption of multiple climate-smart agricultural practices in the Indo-Gangetic Plains of India. Natural Resources Forum, 42(3), 141-158. https://doi.org/10.1111/1477-8947.12152.

Aryal, J. P., Sapkota, T. B., Jat, M. L., \& Bishnoi, D. K. (2015b). On-farm economic and environmental impact of zero-tillage wehat: A case of North-west India. Experimental Agriculture, 51(1), 1-16. https://doi.org/10.1017/S001447971400012X.

Aryal, J. P., Sapkota, T. B., Rahut, D. B., \& Jat, M. L. (2019). Agricultural Sustainability under emerging climatic variability: Role of climate smart agriculture and relevant policies in India. International Journal of Innovation and Sustainable Development (in press). https://www.inderscien ce.com/info/ingeneral/forthcoming.php?jcode=IJISD.

Aryal, J. P., Sapkota, T. B., Stirling, C. M., Jat, M. L., Jat, H. S., Rai, M., et al. (2016a). Conservation agriculture-based wheat production better copes with extreme climate events than conventional tillage-based systems: A case of untimely excess rainfall in Haryana, India. Agriculture, Ecosystems \& Environment, 233, 325-335. https://doi.org/10.1016/j.agee.2016.09.013.

Baker, J. M., Ochsner, T. E., Venterea, R. T., \& Griffis, T. J. (2007). Tillage and soil carbon sequestration-What do we really know? Agriculture, Ecosystems \& Environment, 118(1), 1-5. https://doi. org/10.1016/j.agee.2006.05.014.

Bijay-Singh, Sharma, R. K., Jaspreet-Kaur, Jat, M. L., Martin, K. L., Yadvinder-Singh, et al. (2011). Assessment of the nitrogen management strategy using an optical sensor for irrigated wheat. Agronomy for Sustainable Development, 31(3), 589-603. https://doi.org/10.1007/s13593-011-0005-5.

Bijay-Singh, Varinderpal-Singh, Purba, J., Sharma, R. K., Jat, M. L., Yadvinder-Singh, et al. (2015). Sitespecific fertilizer nitrogen management in irrigated transplanted rice (Oryza sativa) using an optical sensor. Precision Agriculture, 16(4), 455-475. https://doi.org/10.1007/s11119-015-9389-6.

Bouman, B., \& Tuong, T. P. (2001). Field water management to save water and increase its productivity in irrigated lowland rice. Agricultural Water Management, 49(1), 11-30.

Buchner, B. K., Oliver, P., Wang, X., Carswell, C., Meattle, C., \& Mazza, F. (2017). Global Landscape of Climate Finance 2017. London: Climate Policy Initiative.

Bustamante, M., Robledo-Abad, C., Harper, R., Mbow, C., Ravindranat, N. H., Sperling, F., et al. (2014). Co-benefits, trade-offs, barriers and policies for greenhouse gas mitigation in the agriculture, forestry and other land use (AFOLU) sector. Global Change Biology, 20(10), 3270-3290. 
Cai, Z., \& Xu, H. (Eds.). (2004). Options for mitigating CH4 emissions from rice fields in China. In Y. Hayashi (Ed.), Material circulation through agro-ecosystems in East Asia and assessment of its environmental impact (Vol. 5, pp. 45-55). Tsukuba: NIAES.

Celikkol Erbas, B., \& Guven Solakoglu, E. (2017). In the presence of climate change, the use of fertilizers and the effect of income on agricultural emissions. Sustainability, 9(11), 1989.

Choudhary, M., Gill, M. A., Kahlown, M. A., \& Hobbs, P. (2002). Evaluation of resource conservation technologies in rice-wheat system of Pakistan. In Developing an action program for farm-level impact in rice-wheat systems of the indo-gangetic plains, New Delhi, India, 25-29 September 2000 (pp. 148).

Deb, A. K., \& Haque, C. E. (2017). Multi-dimensional coping and adaptation strategies of small-scale fishing communities of Bangladesh to climate change induced stressors. International Journal of Climate Change Strategies and Management, 9(4), 446-468.

Dixon, R. (1995). Agroforestry systems: Sources of sinks of greenhouse gases? Agroforestry Systems, 31(2), 99-116.

FAOSTAT. (2017). FAOSTAT. In Food and agriculture organization of the United Nations. Rome, Italy.

Farnworth, C. R., Stirling, C., Sapkota, T. B., Jat, M., Misiko, M., \& Attwood, S. (2017). Gender and inorganic nitrogen: What are the implications of moving towards a more balanced use of nitrogen fertilizer in the tropics? International Journal of Agricultural Sustainability, 15(2), 136-152.

Farooq, M., Siddique, K. H. M., Rehman, H., Aziz, T., Lee, D.-J., \& Wahid, A. (2011). Rice direct seeding: Experiences, challenges and opportunities. Soil and Tillage Research, 111(2), 87-98. https://doi. org/10.1016/j.still.2010.10.008.

Feliciano, D., Ledo, A., Hillier, J., \& Nayak, D. R. (2018). Which agroforestry options give the greatest soil and above ground carbon benefits in different world regions? Agriculture, Ecosystems \& Environment, 254, 117-129. https://doi.org/10.1016/j.agee.2017.11.032.

Gathala, M. K., Kumar, V., Sharma, P. C., Saharawat, Y. S., Jat, H. S., Singh, M., et al. (2013). Optimizing intensive cereal-based cropping systems addressing current and future drivers of agricultural change in the northwestern Indo-Gangetic Plains of India. Agriculture, Ecosystems \& Environment, 177, 85-97. https://doi.org/10.1016/j.agee.2013.06.002.

Gathala, M. K., Ladha, J., Kumar, V., Saharawat, Y. S., Kumar, V., Sharma, P. K., et al. (2011). Tillage and crop establishment affects sustainability of South Asian rice-wheat system. Agronomy Journal, 103(4), 961-971.

Gerber, P. J., Henderson, B., \& Makkar, H. P. (2013a). Mitigation of greenhouse gas emissions in livestock production. A review of technical options for non-CO2 emissions. Rome: FAO.

Gerber, P. J., Steinfeld, H., Henderson, B., Mottet, A., Opio, C., Dijkman, J., et al. (2013b). Tackling climate change through livestock: A global assessment of emissions and mitigation opportunities. Rome: Food and Agriculture Organization of the United Nations (FAO).

Gil, S. V., Becker, A., Oddino, C., Zuza, M., Marinelli, A., \& March, G. (2009). Field trial assessment of biological, chemical, and physical responses of soil to tillage intensity, fertilization, and grazing. Environmental Management, 44(2), 378-386.

Gill, G. (2014). An assessment of the impact of laser-assisted precision land levelling technology as a component of climate-smart agriculture in the state of Haryana, India.

Grace, P. R., Antle, J., Aggarwal, P. K., Ogle, S., Paustian, K., \& Basso, B. (2012). Soil carbon sequestration and associated economic costs for farming systems of the Indo-Gangetic Plain: A metaanalysis. Agriculture, Ecosystems \& Environment, 146(1), 137-146. https://doi.org/10.1016/j. agee.2011.10.019.

Grace, P. R., Harrington, L., Jain, M., \& Robertson, G. P. (2003). Long-term sustainability of the tropical and subtropical rice-wheat system: An environmental perspective (pp. 27-43). Issues and Impacts (improvingthepro): Improving the productivity and sustainability of rice-wheat systems.

Gupta, R., \& Seth, A. (2007). A review of resource conserving technologies for sustainable management of the rice-wheat cropping systems of the Indo-Gangetic plains (IGP). Crop Protection, 26(3), 436-447. https://doi.org/10.1016/j.cropro.2006.04.030.

Halvorson, A. D., Wienhold, B. J., \& Black, A. L. (2002). Tillage, nitrogen, and cropping system effects on soil carbon sequestration. Soil Science Society of America Journal, 66(3), 906-912.

Herrero, M., Henderson, B., Havlík, P., Thornton, P. K., Conant, R. T., Smith, P., et al. (2016). Greenhouse gas mitigation potentials in the livestock sector. Nature Climate Change, 6, 452. https://doi. org/10.1038/nclimate2925.

IRRI. (2018). GHG mitigation on rice. International Rice Research Institute, http://ghgmitigation.irri. org/our-work/bangladesh. Accessed March 14, 2018.

IPCC. (2006). 2006 IPCC guidelines for national greenhouse gas inventories, prepared by the national greenhouse gas inventories programme. IGES Japan. 
IPCC. (2014). Climate change 2014: Mitigation of climate change. In O. Edenhofer, R. Pichs-Madruga, Y. Sokona, E. Farahani, S. Kadner, K. Seyboth, A. Adler, I. Baum, S. Brunner, P. Eickemeier, B. Kriemann, J. Savolainen, S. Schlömer, C. von Stechow, T. Zwickel, \& J. C. Minx (Eds.), Contribution of working group III to the fifth assessment report of the intergovernmental panel on climate change. Cambridge, New York, NY: Cambridge University Press, Intergovernmental Panel on Climate Change (IPCC).

Jat, M. L., Dagar, J. C., Sapkota, T. B., Yadvinder, S., Govaerts, B., Ridaura, S. L., et al. (2016). Chapter three-Climate change and agriculture: Adaptation strategies and mitigation opportunities for food security in South Asia and Latin America. In D. L. Sparks (Ed.), Advances in agronomy (Vol. 137, pp. 127-235). London: Academic Press.

Jat, R. K., Sapkota, T. B., Singh, R. G., Jat, M. L., Kumar, M., \& Gupta, R. K. (2014). Seven years of conservation agriculture in a rice-wheat rotation of Eastern Gangetic Plains of South Asia: Yield trends and economic profitability. Field Crops Research, 164, 199-210. https://doi.org/10.1016/j. fcr.2014.04.015.

Jat, M. L., Singh, Y., Gill, G., Sidhu, H., Aryal, J. P., Stirling, C., et al. (2015). Laser assisted precision land leveling: Impacts in irrigated intensive production systems of South Asia. Advances in soil science, 323-352.

Kar, A., Garg, B., Singh, M., \& Kathju, S. (2009). Trends in Arid Zone Research in India. Jodhpur, Rajasthan: Central Arid Zone Research Institute.

Kassam, A., Friedrich, T., Shaxson, F., \& Pretty, J. (2009). The spread of conservation agriculture: Justification, sustainability and uptake. International Journal of Agricultural Sustainability, 7(4), 292-320.

Khatri-Chhetri, A., Aryal, J. P., Sapkota, T. B., \& Khurana, R. (2016). Economic benefits of climatesmart agricultural practices to smallholder farmers in the Indo-Gangetic Plains of India. Current Science, 110(7), 1251-1256.

LaHue, G. T., Chaney, R. L., Adviento-Borbe, M. A., \& Linquist, B. A. (2016). Alternate wetting and drying in high yielding direct-seeded rice systems accomplishes multiple environmental and agronomic objectives. Agriculture, Ecosystems \& Environment, 229, 30-39. https://doi.org/10.1016/j. agee.2016.05.020.

Lal, R. (2004). Soil carbon sequestration impacts on global climate change and food security. Science, 304(5677), 1623-1627. https://doi.org/10.1126/science.1097396.

Lal, R. (2015). Sequestering carbon and increasing productivity by conservation agriculture. Journal of Soil and Water Conservation, 70(3), 55A-62A.

Lampayan, R. M., Rejesus, R. M., Singleton, G. R., \& Bouman, B. A. M. (2015). Adoption and economics of alternate wetting and drying water management for irrigated lowland rice. Field Crops Research, 170, 95-108. https://doi.org/10.1016/j.fcr.2014.10.013.

Landesa. (2012). Land rights and agricultural productivity. Washington, DC: Landesa Rural Development Institute.

Lewandowsky, S., Oreskes, N., Risbey, J. S., Newell, B. R., \& Smithson, M. (2015). Seepage: Climate change denial and its effect on the scientific community. Global Environmental Change, 33, 1-13. https://doi.org/10.1016/j.gloenvcha.2015.02.013.

Lin, B. B. (2011). Resilience in agriculture through crop diversification: Adaptive management for environmental change. BioScience, 61(3), 183-193. https://doi.org/10.1525/bio.2011.61.3.4.

Majumdar, D., Rastogi, M., Kumar, S., Pathak, H., Jain, M., \& Kumar, U. (2000). Nitrous oxide emissions from an alluvial soil with different nitrogenous fertilizers and nitrogen levels. Journal of the Indian Society of Soil Science, 48(4), 732-741.

Makundi, W. R., \& Sathaye, J. A. (2004). GHG Mitigation Potential and Cost in Tropical Forestry - Relative Role for Agroforestry. In R. Wassmann \& P. L. G. Vlek (Eds.), Tropical agriculture in transition-Opportunities for mitigating greenhouse gas emissions? (pp. 235-260). Dordrecht: Springer Netherlands.

McCarl, B. A., \& Sands, R. D. (2007). Competitiveness of terrestrial greenhouse gas offsets: Are they a bridge to the future? Climatic Change, 80(1), 109-126. https://doi.org/10.1007/s10584-006-9168-5.

Mottet, A., Henderson, B., Opio, C., Falcucci, A., Tempio, G., Silvestri, S., et al. (2017). Climate change mitigation and productivity gains in livestock supply chains: Insights from regional case studies. Regional Environmental Change, 17(1), 129-141. https://doi.org/10.1007/s10113-016-0986-3.

Nelson, G. C. (2009). Agriculture and climate change: An agenda for negotiation in Copenhagen (Vol. 16). Washington, DC: International Food Policy Research Institute.

Pampolino, M. F., Witt, C., Pasuquin, J. M., Johnston, A., \& Fisher, M. J. (2012). Development approach and evaluation of the Nutrient Expert software for nutrient management in cereal crops. Computers and Electronics in Agriculture, 88, 103-110. https://doi.org/10.1016/j.compag.2012.07.007. 
Pathak, H., Sankhyan, S., Dubey, D. S., Bhatia, A., \& Jain, N. (2013). Dry direct-seeding of rice for mitigating greenhouse gas emission: Field experimentation and simulation. Paddy and Water Environment, 11(1), 593-601. https://doi.org/10.1007/s10333-012-0352-0.

Patra, N. K., \& Babu, S.C. (2017). Mapping Indian agricultural emissions: Lessons for food system transformation and policy support for climate-smart agriculture. International Food Policy Research Institute (IFPRI). IFPRI discussion paper 01660, p. 39.

Powlson, D. S., Stirling, C. M., Jat, M. L., Gerard, B. G., Palm, C. A., Sanchez, P. A., et al. (2014). Limited potential of no-till agriculture for climate change mitigation. Nature Climate Change, 4, 678. https:// doi.org/10.1038/nclimate2292.

Powlson, D. S., Stirling, C. M., Thierfelder, C., White, R. P., \& Jat, M. L. (2016). Does conservation agriculture deliver climate change mitigation through soil carbon sequestration in tropical agro-ecosystems? Agriculture, Ecosystems \& Environment, 220, 164-174. https://doi.org/10.1016/j.agee.2016.01.005.

Pradhan, B. B., Shrestha, R. M., Hoa, N. T., \& Matsuoka, Y. (2017). Carbon prices and greenhouse gases abatement from agriculture, forestry and land use in Nepal. Global Environmental Change, 43, 26-36. https://doi.org/10.1016/j.gloenvcha.2017.01.005.

Richards, M., \& Sander, B. O. (2014). Alternate wetting and drying in irrigated rice : Implementation guidance for policymakers and investors. In Practice brief on climate-smart agriculture. Copenhagen, Denmark: CGIAR Research Program on Climate Change, Agriculture and Food Security (CCAFS).

Rickman, J. (2002). Manual for laser land leveling (Vol. Vol. 5, Rice-wheat consortium technical bulletin series). New Delhi: Rice-Wheat Consortium for the Indo-Gangetic Plains.

Rothausen, S. G., \& Conway, D. (2011). Greenhouse-gas emissions from energy use in the water sector. Nature Climate Change, 1(4), 210.

Sapkota, T. B. (2012). Conservation tillage impact on soil aggregation, organic matter turnover and biodiversity. In Organic fertilisation, soil quality and human health (pp. 141-160). Springer.

Sapkota, T. B., Jat, M. L., Aryal, J. P., Jat, R., \& Khatri-Chhetri, A. (2015a). Climate change adaptation, greenhouse gas mitigation and economic profitability of conservation agriculture: Some examples from cereal systems of Indo-Gangetic Plains. Journal of Integrative Agriculture, 14(8), 1524-1533.

Sapkota, T. B., Jat, M. L., Shankar, V., Singh, L. K., Rai, M., Grewal, M. S., et al. (2015b). Tillage, residue and nitrogen management effects on methane and nitrous oxide emission from rice-wheat system of Indian Northwest Indo-Gangetic Plains. Journal of Integrative Environmental Sciences, 12(Supp 1), 31-46. https://doi.org/10.1080/1943815X.2015.1110181.

Sapkota, T. B., Jat, R., Singh, R., Jat, M., Stirling, C. M., Jat, M., et al. (2017a). Soil organic carbon changes after seven years of conservation agriculture in a rice-wheat system of the eastern IndoGangetic Plains. Soil Use and Management, 33(1), 81-89.

Sapkota, T. B., Majumdar, K., Jat, M. L., Kumar, A., Bishnoi, D. K., McDonald, A. J., et al. (2014). Precision nutrient management in conservation agriculture based wheat production of Northwest India: Profitability, nutrient use efficiency and environmental footprint. Field Crops Research, 155, 233-244. https://doi.org/10.1016/j.fcr.2013.09.001.

Sapkota, T. B., Majumdar, K., Khurana, R., Jat, R. K., Stirling, C. M., \& Jat, M. L. (2016). Precision Nutrient Management under Conservation Agriculture-based Cereal Systems in South Asia ( $\mathrm{p}$. 131). Climate Change and Agricultural Development: Improving Resilience through Climate Smart Agriculture, Agroecology and Conservation.

Sapkota, T., Shankar, V., Rai, M., Jat, M., Stirling, C., Singh, L., et al. (2017b). Reducing global warming potential through sustainable intensification of basmati rice-wheat systems in India. Sustainability, 9(6), 1044.

Sapkota, T. B., Vetter, S. H., Jat, M. L., Sirohi, S., Shirsath, P. B., Singh, R., et al. (2019). Cost-effective opportunities for climate change mitigation in Indian agriculture. Science of the Total Environment, 655, 1342-1354.

Sathaye, J. A., \& Ravindranath, N. (1998). Climate change mitigation in the energy and forestry sectors of developing countries. Annual Review of Energy and the Environment, 23(1), 387-437.

Singh, O., Singh, H., Badal, P., Singh, R., \& Pandey, D. (2010). Impact of resource conservation technologies on carbon emission in major wheat growing regions of India. Indian Journal of Agricultural Economics, 65(902-2016-67944).

Siopongco, J., Wassmann, R., \& Sander, B. O. (2013). Alternate wetting and drying in Philippine rice production: Feasibility study for a Clean Development Mechanism. IRRI technical Bulletin (Vol. 14). Los Baños, Philippine: International Rice Research Institute (IRRI).

Smith, P., Bustamante, M., Ahammad, H., Clark, H., Dong, H., Elsiddig, E. A., et al. (2014). Agriculture, forestry and other land use (AFOLU). In Climate change 2014: Mitigation of climate change. Contribution of working group III to the fifth assessment report of the intergovernmental panel on climate change (pp. 811-922). Cambridge University Press. 
Smith, P., Martino, D., Cai, Z., Gwary, D., Janzen, H., Kumar, P., et al. (2007a). Agriculture. In B. Metz, O. R. Davidson, P. R. Bosch, R. Dave, \& L. A. Meyer (Eds.), Climate Change 2007: Mitigation. Contribution of working group III to the fourth assessment report of the intergovernmental panel on climate change (pp. 499-541). Cambridge: Cambridge University Press.

Smith, P., Martino, D., Cai, Z., Gwary, D., Janzen, H., Kumar, P., et al. (2007b). Policy and technological constraints to implementation of greenhouse gas mitigation options in agriculture. Agriculture, Ecosystems \& Environment, 118(1), 6-28. https://doi.org/10.1016/j.agee.2006.06.006.

Smith, P., Martino, D., Cai, Z., Gwary, D., Janzen, H., Kumar, P., et al. (2008). Greenhouse gas mitigation in agriculture. Philosophical transactions of the royal Society B: Biological Sciences, 363(1492), 789-813.

Steenwerth, K. L., Hodson, A. K., Bloom, A. J., Carter, M. R., Cattaneo, A., Chartres, C. J., et al. (2014). Climate-smart agriculture global research agenda: Scientific basis for action. Agriculture \& Food Security, 3(1), 11. https://doi.org/10.1186/2048-7010-3-11.

Steinfeld, H., Gerber, P., Wassenaar, T., Castel, V., Rosales, M., Rosales, M., et al. (2006). Livestock's long shadow: Environmental issues and options. Rome: Food \& Agriculture Organization.

Tewatia, R., Rattan, R., Bhende, S., \& Kumar, L. (2017). Nutrient use and balances in India with special reference to phosphorus and potassium. Indian Journal of Fertility, 13, 20-29.

Thomas, G. A., Dalal, R. C., \& Standley, J. (2007). No-till effects on organic matter, pH, cation exchange capacity and nutrient distribution in a Luvisol in the semi-arid subtropics. Soil and Tillage Research, 94(2), 295-304. https://doi.org/10.1016/j.still.2006.08.005.

Thornton, P. K., \& Herrero, M. (2010). Potential for reduced methane and carbon dioxide emissions from livestock and pasture management in the tropics. Proceedings of the National Academy of Sciences, 107(46), 19667. https://doi.org/10.1073/pnas.0912890107.

UNFCCC. (2015). Synthesis report on the aggregate effect of the intended nationally determined contributions.

UNFCCC. (2017). Land use and climate change [WWW Document]. Issues Relat. to Agric. URL http:// unfccc.int/land_use_and_climate_change/items/8792.php. Accessed September 4, 2018.

Uprety, D., Dhar, S., Hongmin, D., Kimball, B. A., Garg, A., \& Upadhyay, J. (2012). Technologies for climate change mitigation: Agriculture sector. UNEP Ris $\varnothing$ Centre on Energy, Climate and Sustainable Development, Technical University of Denmark, Frederiksborg.

Valin, H., Havlík, P., Mosnier, A., Herrero, M., Schmid, E., \& Obersteiner, M. (2013). Agricultural productivity and greenhouse gas emissions: Trade-offs or synergies between mitigation and food security? Environmental Research Letters, 8(3), 035019.

Verchot, L. V., Van Noordwijk, M., Kandji, S., Tomich, T., Ong, C., Albrecht, A., et al. (2007). Climate change: Linking adaptation and mitigation through agroforestry. Mitigation and Adaptation Strategies for Global Change, 12(5), 901-918. https://doi.org/10.1007/s11027-007-9105-6.

Vetter, S. H., Sapkota, T. B., Hillier, J., Stirling, C. M., Macdiarmid, J. I., Aleksandrowicz, L., et al. (2017). Greenhouse gas emissions from agricultural food production to supply Indian diets: Implications for climate change mitigation. Agriculture, Ecosystems \& Environment, 237, 234-241. https://doi. org/10.1016/j.agee.2016.12.024.

Wassmann, R., Hosen, Y., \& Sumfleth, K. (2009). Reducing methane emissions from irrigated rice. International Food Policy Research Institute (IFPRI).

West, T. O., \& Post, W. M. (2002). Soil organic carbon sequestration rates by tillage and crop rotation. Soil Science Society of America Journal, 66, 1930-1946. https://doi.org/10.2136/sssaj2002.1930.

World Bank. (2010). India: Making insurance markets work for farmers [http://www.worldbank.org/en/resul ts/2010/11/01/india-making-insurance-markets-work-for-farmers]. Washington, DC, USA: World Bank Group.

World Bank. (2013a). Data: Climate change. World Bank, Washington DC, USA. http://data.worldbank.org/ topic/climate-change. Accessed June, 2017.

World Bank. (2013b). World bank data on fertilizer consumption. Washington DC, USA. https://data.world bank.org/indicator/AG.CON.FERT.ZS. Accessed June, 2017.

Xu, H., Cai, Z. C., Jia, Z. J., \& Tsuruta, H. (2000). Effect of land management in winter crop season on CH4 emission during the following flooded and rice-growing period. Nutrient Cycling in Agroecosystems, 58(1), 327-332. https://doi.org/10.1023/a:1009823425806.

Yadav, S., Humphreys, E., Li, T., Gill, G., \& Kukal, S. S. (2012). Evaluation of tradeoffs in land and water productivity of dry seeded rice as affected by irrigation schedule. Field Crops Research, 128, 180190. https://doi.org/10.1016/j.fcr.2012.01.005.

Yang, J., Huang, D., Duan, H., Tan, G., \& Zhang, J. (2009). Alternate wetting and moderate soil drying increases grain yield and reduces cadmium accumulation in rice grains. Journal of the Science of Food and Agriculture, 89(10), 1728-1736. 
Yao, F., Huang, J., Cui, K., Nie, L., Xiang, J., Liu, X., et al. (2012). Agronomic performance of highyielding rice variety grown under alternate wetting and drying irrigation. Field Crops Research, 126, 16-22. https://doi.org/10.1016/j.fcr.2011.09.018.

Ye, Y., Liang, X., Chen, Y., Liu, J., Gu, J., Guo, R., et al. (2013). Alternate wetting and drying irrigation and controlled-release nitrogen fertilizer in late-season rice. Effects on dry matter accumulation, yield, water and nitrogen use. Field Crops Research, 144, 212-224. https://doi.org/10.1016/j. fcr.2012.12.003.

Zhang, Y., Tang, Q., Peng, S., Xing, D., Qin, J., Laza, R. C., et al. (2012). Water use efficiency and physiological response of rice cultivars under alternate wetting and drying conditions. The Scientific World Journal.

Zhang, H., Xue, Y., Wang, Z., Yang, J., \& Zhang, J. (2009). An alternate wetting and moderate soil drying regime improves root and shoot growth in rice. Crop Science, 49(6), 2246-2260.

Publisher's Note Springer Nature remains neutral with regard to jurisdictional claims in published maps and institutional affiliations. 